\title{
Effect of Various Method of Weed Management on Growth and Yield of Vegetable Pea (Pisum sativum. spp. Hortense. L) Involving the Use of Implements and Herbicides
}

\author{
Vikram Singh ${ }^{1}$, Kuldeep Kumar ${ }^{2}$, Pradip Kumar Saini ${ }^{4 *}$, \\ Ankit Singh Chauhan ${ }^{1}$ and D.P. Singh ${ }^{1}$ \\ ${ }^{1}$ Department of Horticulture, ${ }^{2}$ Department of Vegetable Science, ${ }^{3}$ Department of Crop \\ Physiology, Chandra Shekhar Azad University of Agriculture and Technology, Kanpur (U.P.), \\ ${ }^{4}$ Narendra Deva University of Agriculture and Technology, \\ Kumarganj, Ayodhya (U.P.), India \\ *Corresponding author
}

\section{A B S T R A C T}

\section{Keywords}

Weed management, Herbicides and Vegetable pea (Pisum sativum spp. hortense. L)

\section{Article Info}

Accepted: 07 February 2019 Available Online: 10 March 2019

\begin{abstract}
Vegetable pea (Pisum sativum spp. Hortense L.) is an important pulse crop. In the present investigation, afield experiment was laid out in randomized block design in three replication Variety - Azad Pea-3, keeping pre-emergence application of pendimethalin (stamp extra 38.7\%) @ $0.75 \mathrm{~kg}$ a.i./ha, stale seed bed glyphosate @1.00 kg a.i./ha, mulching and hand weeding in plot. This field experiment was carried out at Kalayanpur, Kanpur during Rabi season 2014-15 and laboratory test were also conducted. Data display that the weed free check method treatment yielded. The highest seed yield of vegetable pea closely followed by hand weeding at 20,40 and 60 DAS. The lowest seed yield was found in weedy check (no weeding). The seed yield of vegetable pea in other treatment was recorded in between these two limits. The growth and yield trials were supported to the seed yield but the maximum BCR was computed under pre-emergence application of pendimethalin (stamp extra 38.7\%) @ $0.75 \mathrm{~kg}$ a.i./ha.
\end{abstract}

\section{Introduction}

Vegetables are richest source of nutrition of the large part of vegetarian demography at the global level. In India, vegetable contribute about $8-10 \%$ edible food intake which is distressingly low as compared to Japan where its share is about $45 \%$. The estimated availability of vegetable in India is around
145-185 gram per capita per day while neutralist advocate 285-300 gram of vegetable in the balance diet. Pulses are gaining more important position in Indian agriculture. After the Green Revolution, India became self sufficient in food grain production. However, India is still lagging behind in pulses production and is dependent on imports for domestic consumption in present days. As 
there is little scope to increase area under pulses, the production can be increased by enhancing the productivity by various agrotechniques. Pea contains nutritional value per 100gram (3.5 oz) energy $339 \mathrm{~kJ}$ (81kcal), carbohydrates $14.45 \mathrm{~g}$, sugars $5.67 \mathrm{~g}$, Dietary fiber 5.1 gram, fat $0.4 \mathrm{~g}$, protein $5.42 \mathrm{~g}$, Vitamin A equiv. $38 \mu \mathrm{g}$, beta carotene $449 \mu \mathrm{g}$, lutein zeaxanthin $2.477 \mu \mathrm{g}$, Thiamine (B1) $0.266 \mathrm{mg}$, Riboflavin (B2) $0.132 \mathrm{mg}$, Niacin (B3) $2.09 \mathrm{mg}$, Vitamin (B6) $0.169 \mathrm{mg}$, Folate (B9) $65 \mu \mathrm{g}$, Vitamin C $40 \mathrm{mg}$, Vitamin E $0.13 \mathrm{mg}$, Vitamin K $24.8 \mu \mathrm{g}$, Calcium $25 \mathrm{mg}$, Iron $1.47 \mathrm{mg}$, Magnesium $33 \mathrm{mg}$, Manganese 0.41mg, Phosphorus $108 \mathrm{mg}$, Potassium 244mg, Sodium $5 \mathrm{mg}$ and zinc $1.24 \mathrm{mg}$. (USDA Nutrient Database).Integrated approach of weed management is always welcomed. Chemical control integrated with cultivations, rotation and hand weeding increase crop yield (Tu et al., 1993). Preemergence of application $0.5 \mathrm{~kg} / \mathrm{ha}$ pendimethalin + hand weeding (30DAS) or $0.5 \mathrm{~kg}$ fluchloralin as pre sowing + hand weeding (30 DAS) have been found better for weed control and pea yield as compared to herbicides alone (Sharma and Vats 1986).

\section{Materials and Methods}

The experiment was carried out at department of vegetable science Kalyanpur, C. S. Azad University of Agriculture and Technology Kanpur during the year 2015-2016. Field experiment was laid out in R.B.D, having three replication and nine treatments and Variety - Azad Pea-3, keeping pre-emergence application of pendimethalin (stamp extra 38.7\%)@0.75 kg a.i./ha, stale seed bed glyphosate@1.00 kg a.i./ha, mulching and hand weeding in plot. $\mathrm{T}_{1}-$ Pre-emergence (PE) application of pendimethalin (stamp extra 38.7\%) @ $0.75 \mathrm{~kg}$ a.i./ha.T. $2^{-}$Preemergence (PE) application of pendimethalin (stamp extra) $0.75 \mathrm{~kg}$ a.i./ha Followed by one hand weeding at 40DAS. T 3 - Stale seed bed by glyphosate @ $1.00 \mathrm{~kg}$ a.i./ha at (15 days before sowing because sowing time for all the treatment will same). $\mathrm{T}_{4}$ - Stale seed bed by glyphosate@1.00 kg a.i./ha Followed by one hand weeding at 40DAS. T5-Mulching with Black polythene. $T_{6}$-Straw mulch or grass mulch. $T_{7-}$ Hand weeding at 20, 40 and 60 days after sowing. $T_{8}$-Weed free check method. $\mathrm{T}_{9}$-Weedy check (No weeding) The highest seed yield of vegetable pea closely followed by hand weeding at 20,40 and 60 DAS. The vegetable research farm is about 10 $\mathrm{km}$ away from Kanpur central railway station in the north western part of the Kanpur city. It is situated in the front of Indian institute of Pulse Research Geographically, Kanpur is situated in gangatic alluvial belt of Central Uttar Pradesh and located between $25^{\circ} 26^{\prime}$ to $26^{\circ} 28^{\prime}$ north latitude and $79^{\circ} 31^{\prime}$ to $80^{\circ} 34^{\prime}$ East longitude at elevation of 127.00meters above mean sea level.

\section{Results and Discussion}

The relavant research studies on improvement of production potential in pea in respect of integrated weed management are meagre and hence the present investigation is aimed to increase the growth and yield attributes in pea with use of chemical, mulching and hand weeding.

\section{Height of plant}

Effect of different treatments on height of the plants has been presented from sowing date to maturity of plants from table 1. Observation pertaining to the height of plant since very beginning was affected by the treatments had manifested the maximum height of the vegetable pea at all the stages of observation. It was clearly indicated that the height of plant mainly governed by weed free check method. Such result is in the conformity with the work of. (Rana et al.,2007, Channappagoudar and Birader et al., 2007, Yousefi et al., 
2007,Travlos et al.,2014 and Shiv Chandrakar et al.,2015) (Fig. 1).

\section{Seed weight per plant}

It is clear from the data that the seed weight per plant, from table 1 . Increased significantly in weed free check method followed by hand weeding at 20,40 and 60 days after sowing. Seed weight per plant is the resultant growth of plant. Data represented for these characters in previous chapter also showed that this treatment has shown its superiority with respect to over all other treatments. The result obtained in this investigation was supported by (Ved Prakash et al., 2000, Emenky et al., 2010, Olorunmaiye, 2010, Brij Bhooshan and Singh, 2014 and Onuh et al., 2015)

\section{Number of seeds per pod}

Number of seeds per pod as affected by the treatments has been presented in table 2. It is clear from the table the superiority of weed free check similar followed by pre emergence application of pendimethalin (stamp extra) $@ 0.75 \mathrm{~kg}$ a.i./ha followed by one hand weeding at 40 DAS. Other treatments which are alone could not make any marked differences in results. Number of seeds per pod character is a dependant on length of pods of Vegetable Pea here it is clear that sufficient number of seeds per pod is available on plant according to plant growth. Weed free check method clearly indicates that besides pre emergence application of pendimethalin (stamp extra)@0.75kg a.i./ha followed by one hand weeding at 40 DAS plays the role in increasing the number of seeds per pod. This result has also corroborated Ramesh Verma et al., (2014) (Fig. 2).

\section{Seed weight (gm)}

100 seed weight as recorded in this experiment has been presented in table 2 . This indicate that weed free check method has over all superior over other treatments. Although there was no much difference among the treatments over this characters. The higher 100 seed weight $(\mathrm{gm})$ of treatment weed free check method is only because of the bigger seed size. Results also conform with the result of Gutiérrez et al., (2001), Emenky et al., (2010) and Madukwe et al., (2012).

Table.1 plant height and seed weight/plant recorded under different treatments

\begin{tabular}{|l|c|c|}
\hline Treatments & $\begin{array}{c}\text { Plant height } \\
(\mathrm{cm})\end{array}$ & $\begin{array}{c}\text { Seed } \\
\text { weight/plant(gm) }\end{array}$ \\
\hline $\begin{array}{l}\text { Pre-emergence ( PE) application of pendimethalin(stamp extra 38.7\%)@0.75 } \\
\text { kg a.i./ha . }\end{array}$ & 53 & 12.05 \\
\hline $\begin{array}{l}\text { Pre-emergence ( PE) application of pendimethalin(stamp extra 38.7\%)@0.75 } \\
\text { kg a.i./ha. Followed by one hand weeding }\end{array}$ & 58 & 12.20 \\
\hline Stale seed bed by glyphosate @ 1.00kg a.i./ha at 15 days before sowing & 50 & 9.60 \\
\hline $\begin{array}{l}\text { Stale seed bed by glyphosate @ 1.00kg a.i./ha Followed by one hand weeding } \\
\text { at 40 DAS }\end{array}$ & 47 & 10.20 \\
\hline Mulching with black polythene. & 54 & 12.20 \\
\hline Straw mulch/ or grass mulch. & 53 & 12.35 \\
\hline Hand weeding at 20,40 and 60 DAS & 58 & 12.80 \\
\hline Weed free check method & 60 & 13.45 \\
\hline Weedy check (no weeding) & 49 & 7.90 \\
\hline CD 5\% & 4.48 & 1.01 \\
\hline CV\% & 3.51 & 3.72 \\
\hline
\end{tabular}


Table.2 No. of seeds /pod and 100 seed weight (gm)

\begin{tabular}{|l|c|c|}
\hline Treatment & $\begin{array}{c}\text { No. of seeds } \\
\text { /pod }\end{array}$ & $\begin{array}{c}100 \text { Seed } \\
\text { weight }(\mathrm{gm})\end{array}$ \\
\hline $\begin{array}{l}\text { Pre-emergence ( PE) application of pendimethalin(stamp extra 38.7\%)@0.75 kg } \\
\text { a.i./ha . }\end{array}$ & 6.45 & 30.20 \\
\hline $\begin{array}{l}\text { Pre-emergence ( PE) application of pendimethalin(stamp extra 38.7\%)@0.75 kg } \\
\text { a.i./ha . Followed by one hand weeding }\end{array}$ & 6.50 & 30.55 \\
\hline Stale seed bed by glyphosate @1.00kg a.i./ha at 15 days before sowing & 4.55 & 24.10 \\
\hline $\begin{array}{l}\text { Stale seed bed by glyphosate @ 1.00kg a.i./ha Followed by one hand weeding at } \\
\text { 40 DAS }\end{array}$ & 4.76 & 25.53 \\
\hline Mulching with black polythene. & 6.35 & 30.52 \\
\hline Straw mulch/ or grass mulch. & 6.26 & 30.95 \\
\hline Hand weeding at 20,40 and 60 DAS & 6.46 & 32.05 \\
\hline Weed free check method. & 6.56 & 33.82 \\
\hline Weedy check (no weeding) & 4.75 & 19.75 \\
\hline CD 5\% & 0.16 & 1.24 \\
\hline CV\% & 1.12 & 1.82 \\
\hline
\end{tabular}

Table.3 Seed yield (Q/ha)

\begin{tabular}{|l|c|}
\hline Treatment & Seed yield (Q/ha.) \\
\hline Pre-emergence ( PE) application of pendimethalin(stamp extra 38.7\%)@0.75 kg a.i./ha . & 14.98 \\
\hline $\begin{array}{l}\text { Pre-emergence ( PE) application of pendimethalin(stamp extra 38.7\%)@0.75 kg a.i./ha . } \\
\text { Followed by one hand weeding }\end{array}$ & 15.17 \\
\hline Stale seed bed by glyphosate @ 1.00kg a.i./ha at 15 days before sowing & 11.93 \\
\hline $\begin{array}{l}\text { Stale seed bed by glyphosate @ 1.00kg a.i./ha Followed by one hand weeding at 40 } \\
\text { DAS }\end{array}$ & 12.65 \\
\hline Mulching with black polythene. & 15.15 \\
\hline Straw mulch/ or grass mulch. & 15.35 \\
\hline Hand weeding at 20,40 and 60 DAS & 15.93 \\
\hline Weed free check method & 16.75 \\
\hline Weedy check (no weeding) & 9.76 \\
\hline CD 5\% & 0.55 \\
\hline CV\% & 1.63 \\
\hline
\end{tabular}

Fig.1 Plant height $(\mathrm{cm})$ and seed weight/plant $(\mathrm{gm})$ influenced by different treatments

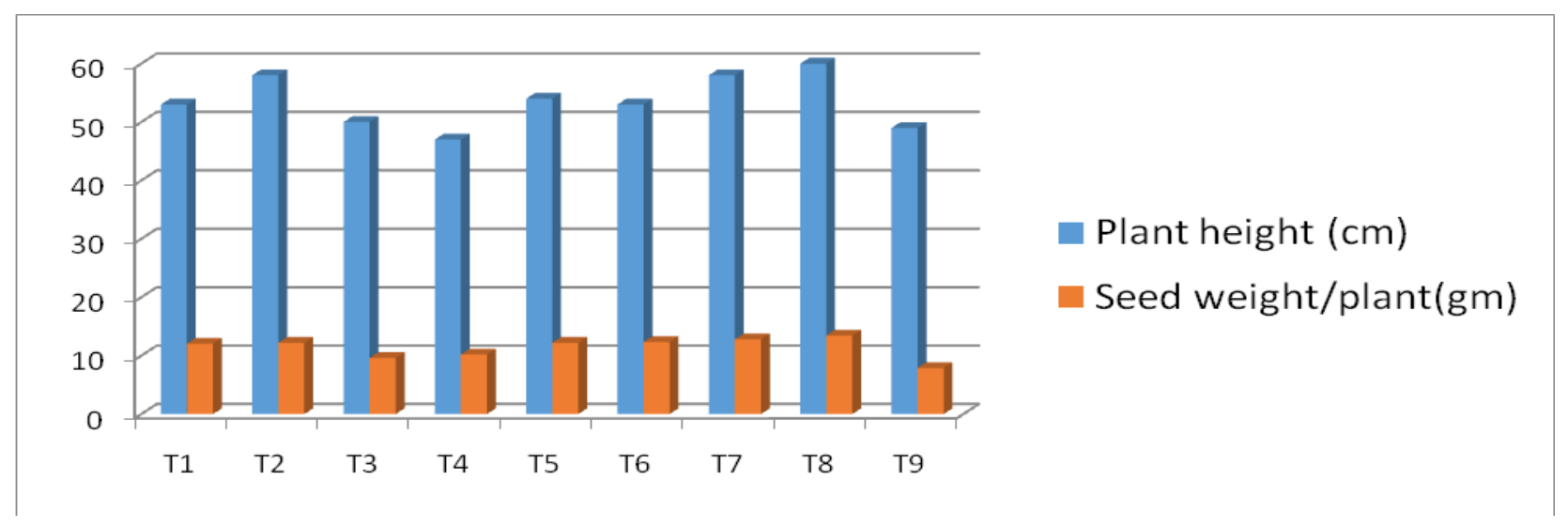


Fig.2 No. of seeds/pod and 100 seed weight (gm) recorded under different treatments

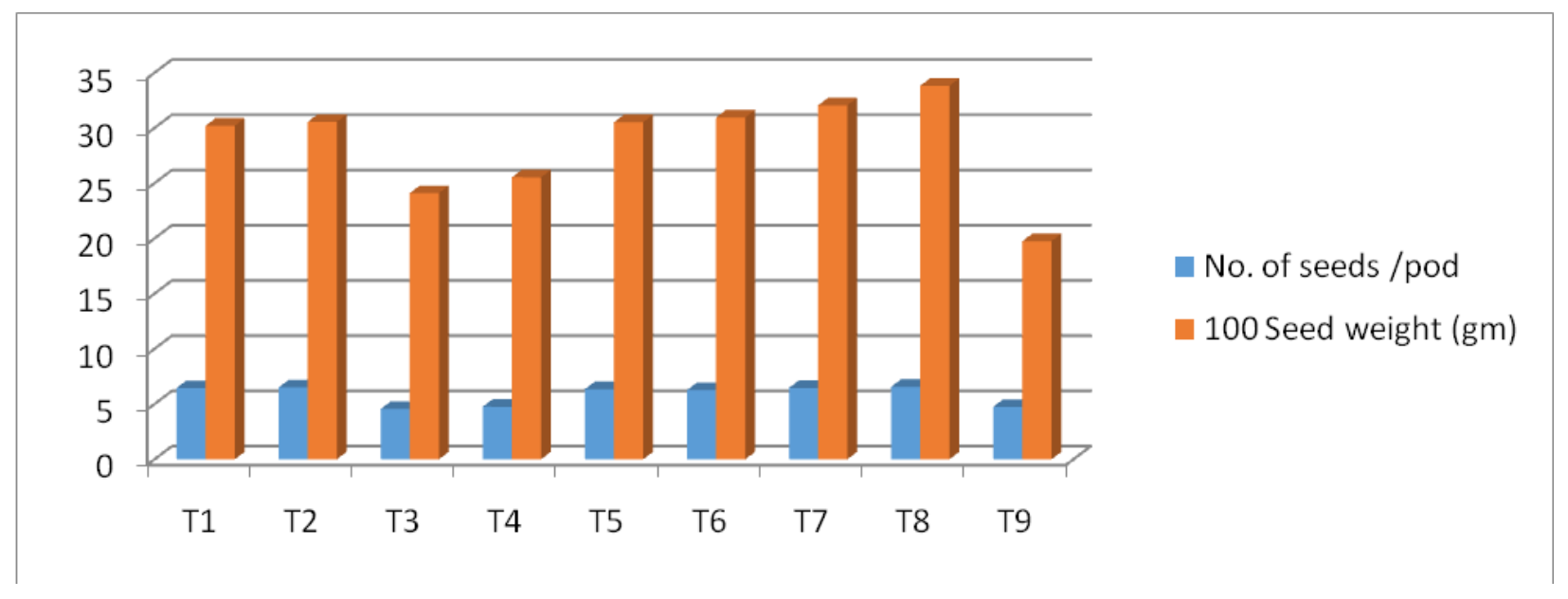

Fig.3 Seed yield/ha

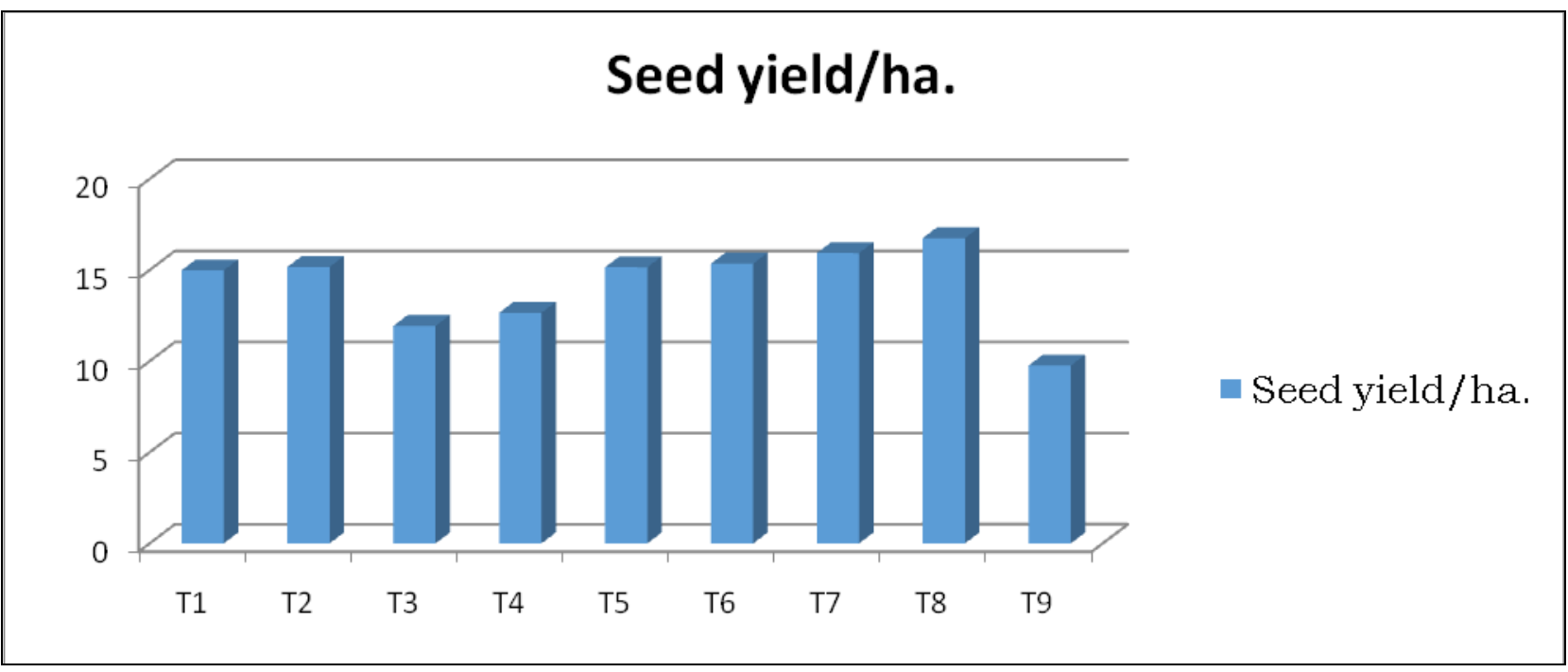

\section{Seed yield per hectare}

The seed yield per hectare as affected by the different treatments have been presented in table 3 observation pertaining to the highest seed yield per hectare was found in the treatment of weed free check method (Fig. 3).

It was clearly indicated that the seed yield per hectare mainly governed weed free check method. It was also clear that the lowest seed yield per hectare in weedy check (no weeding). Such results were in the conformity with the work of Vaishya et al., (1999), Tiwari and Tiwari (2002) and Muhammad et al., (2014).

In conclusion, on the basis of result of the present investigation made during winter season 2014-15, the following conclusion may be drawn as per objective. Plant height effected by the treatments had manifested the maximum height of the vegetable plant indicate that the height of plant was maximum in weed free check method. Seed weight showed that this treatment has sown its 
superiority with respect to all other treatments. Number of seeds per pod clearly indicates that besides pre emergence application of pendimethalin (stamp extra) $@ 0.75 \mathrm{~kg}$ a.i. /ha followed by one hand weeding at $40 \mathrm{DAS}$, plays the role in increasing the number of seeds per pod. Seed yield clearly indicate that the seed yield per hectare mainly governed weed free check method. It was also clear that the lowest seed yield per hectare in weedy check (no weeding). Observation represented that the weed free check method treatment yielded. Highest kernel yield of vegetable pea closely followed by hand weeding at 20, 40 and 60 DAS. The growth and yield trial were supported to the yield but the maximum BCR was computed under pre-emergence application of pendimethalin (stamp extra $38.7 \%$ @ $0.75 \mathrm{~kg}$ a.i./ha).

\section{Acknowledgments}

The authors are thankful to the Department of Horticulture (Vegetable), Chandra shekhar Azad University of Agriculture and Technology, Kanpur, for supporting and funding to develop the present research.

\section{References}

BrijBhooshan and Singh, V.K (2014). Effect of planting method, irrigation schedule and weed management practice on the performance of fieldpea (Pisumsativum L. arvense). Journal of Food Legumes 27(2): 112-116

Channappagoudar, B.B. and Biradar, N.R. (2007). Physiological approaches for weed management in soybean and redgram (4:2 RP) intercropping system. Karnataka Journal of Agricultural Sciences 20(2): 241-244.

Emenky, F. A. O., Khalaf, A. S. and Salim, N. M. (2010). Department of Horticulture, College of Agriculture,
University of Duhok, Kurdistan Region, Iraq. Pakistan Journal of Weed Science Research 16(2): 189198.

Gutiérrez, W., Medrano, C., Villalobos, Y., Medina, B., Narváez, J.;Martínez, N., Montiel, R., Higuera, A.and Báez, J. (2001). Weed control on cowpea (Vigna unguiculata (L.)) Walp under direct sowing in Maracaibo plateau, Venezuela. RevistaUnellez de Ciencia y Tecnología, ProducciónAgrícola 19: 115-124

Madukwe, D. K., Ogbuehi, H. C., Onuh, M. O (2012). Effects of weed control methods on the growth and yield of cowpea (Vigna unguiculata (L.) Walp) under rain-fed conditions of owerri. American-Eurasian Journal of Agricultural \& Environmental Sciences 12 (11): 1426-1430

Mohammad Amin, Khan, M. J., Jan, M. T., Abdul Latif, Masood-ur-Rehman and MohammadArif (2014). Weed biomass and growth of mungbean as affected by tillage practices and sowing methods. Sarhad Journal of Agriculture 30 (2) 227-230

Olorunmaiye, K. S.(2010) Reproductive performance of two cowpea (Vigna unguiculata (L) Walp) varieties Ife brown and TVX3236 as influenced by Imidazolinone and Dinitroaniline herbicides. Australian Journal of Agricultural Engineering 1(3): 101105.

Onuh, M. O., Ukonu, E. N., Ibe, A. E., Madukwe, D. K. and Iheaturu, D. E. (2015). Performance of cowpea (Vigna unguiculata (L) Walp) as influence by different weed control methods. Journal of Biology, Agriculture and Healthcare 5(17): 178-185.

Ramesh Verma, Nepalia, V. and Kumawat, S. K. (2014). Influence of weed control 
and sulphur nutrition on weed dynamics and productivity of pea (Pisum sativum L.). Indian Journal of weed Science 36 (3/4 ): 285-286.

Rana, M. C., Amar Singh, Rana, S. S.and Naveen Kumar (2007). Integrated pest management in pea (Pisum sativum) under Lahaul valley conditions of Himachal Pradesh. Indian Journal of Agricultural Sciences 77 ( 1 ): 59-61

Sharma,A.R. and Vats, O.P (1986) Indian journal Agron., 33: 214-216

Shiv Chandrakar, Akanksha Sharma, and Gajendra Chandrakar (2015). Response of integrated weed management to different varieties of chickpea (Cicer arietinum L.). Trends in Bioscience 8(3): 833-835.

Tewari, A. N. and Tiwari, S. N. (2002).Chemical control of Asphodelus tenuifoliusin testing gram under rainfed condition. Indian $J$. of Agril. Sci. (communicated).
Travlos, I. S., Kanatas, P. J., Tsioros, S., Papastylianou, P., Papatheohari, Y. and Bilalis, D. (2014). Green manure and pendimethalin impact on oriental sun-cured tobacco. Agronomy Journal 106 (4): $1225-1230$

Tu, H et al.,(1993) Scientia Agricultura Sinica 26: 49-56.

Vaishya, R. D., Rai, O. P. and Singh, R. K.(1999). Weed control in field pea with pre and post emergence herbicides. Indian Journal of Pulses Research 12(2): 201-205.

VedPrakash, Pandey, A. K., Singh, R. D. and Mani, V. P. (2000). Integrated weed management in gardenpea under midhills of north-west Himalayas. Indian Journal of Weed Science 32(2): 7-11.

Yousefi, A.R. Alizadeh, H.M. and Rahimian, H. (2007). Broad leaf weed control in chickpea (Cicer arietinum L.) with pre-and post-emergence herbicides. Research on Crops 8 (3): 560-564

\section{How to cite this article:}

Vikram Singh, Kuldeep Kumar, Pradip Kumar Saini, Ankit Singh Chauhan and Singh, D.P. 2019. Effect of Various Method of Weed Management on Growth and Yield of Vegetable Pea (Pisum sativum. Spp. Hortense. L) involving the Use of Implements and Herbicides. Int.J.Curr.Microbiol.App.Sci. 8(03): 521-527. doi: https://doi.org/10.20546/ijcmas.2019.803.063 